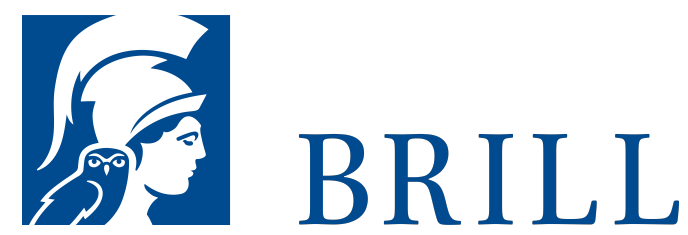

\title{
Zeugnis, Liebe und Widerstand
}

Der Rhönbruderhof $1933^{-1937}$

Author: Thomas Nauerth

„Die Menschen sind friedliebend und weigern sich, den Hitlergruß zu bringen. Sie grüßten mit den Worten, Alles Gute für Hitler und alles Heil von Christus.' Die nat. soz. Geste mit der erhobenen Hand unterließen sie“, so schrieb eine niederländische Zeitung über die 1937 ausgewiesene hutterische Bruderhofgemeinschaft.

Unter nationalsozialistischer Herrschaft hatten sie vier Jahre lang ihr strikt an der Bergpredigt orientiertes christlich kommunitäres Leben fortgesetzt, bevor sie aus Deutschland vertrieben wurden.

Vom Zeugnis über die Liebe zum Widerstand, so kann der Weg des Bruderhofs in der NS-Zeit beschrieben werden. Sie fanden eigene und besondere Antworten auf die Frage, ob und wie in christlicher Perspektive gewaltfreier Widerstand zu leisten ist. Sie suchten die Begegnung mit führenden Vertretern der bekennenden Kirche (Karl Barth, Martin Niemöller, Dietrich Bonhoeffer), sie bauten ein internationales Freundschaftsnetz in die Schweiz, nach Liechtenstein, in die Niederlande und schließlich nach Großbritannien auf und sie nutzten ihre internationale Vernetzung, um sich immer wieder geschickt der NS-Diktatur zu entziehen. Aus der Geschichte dieser Gemeinschaft ergeben sich viele neue und ungewohnte Perspektiven auf die Zeit von 1933-1937. Ihre Erfahrungen sind daher für das Themenfeld „Christen im Dritten Reich“ insgesamt von Bedeutung.

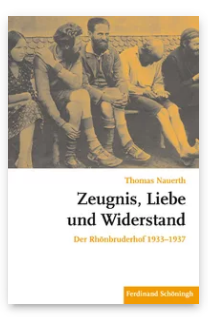

Pages: 369 Seiten, $15 \mathrm{~s} / \mathrm{w}$

Abb.

Language:

German

Subjects:

General, Theology and

World

Christianity

Publisher: Brill|

Schöningh

E-Book (PDF)

Released online:

13 Dec 2017

ISBN: 978-3-

657-78777-7

List price

Hardback

Publication date:

o1 Dec 2017

ISBN: 978-3-

506-78777-4

List price 
Dr. theol. Thomas Nauerth ist apl. Prof. am Institut für Katholische Theologie der Universität Osnabrück.

For more information see brill.com

\section{Order information: Order online at brill.com +44330 333 0049 | customerservices@brill.com Submission information: brill.com/authors}

Titles published by Brill |Fink, Brill | mentis or Brill | Schöningh: +49(o)71 5413279216 | brill@brocom.de 